\title{
THE LIMITS OF THE LAWYER'S DISCRETION AND THE LAW OF LEGAL ETHICS: NATIONAL STUDENT MARKETING REVISITED
}

\section{Ray Patterson*}

The SEC v. National Student Marketing Corp. case, ${ }^{1}$ representing "a substantial departure from traditional standards of care and priorities of duties for securities lawyers," 2 inay well be one of the most significant cases on legal ethics in the history of the American legal profession. Despite the specialized bar to which it is directed, its impact is not limited to securities lawyers. Indeed, the significance of the case is its potential effect on the lawyer's exercise of discretion in all areas of practice. The true significance of the case can only be appreciated when it it is viewed in light of both the traditional constraints on the lawyer's discretion and the factors that have shaped the rules of legal ethics for lawyers.

Constraints on the lawyer's exercise of discretion have traditionally been determined by reference to the principle of loyalty to the client. $^{3}$ It is this principle that is used to justify the major rules of legal

* Dean and Professor of Law, Emory University (on leave, 1979-80); Visiting Professor of Law, University of Georgia, 1979-80. A.B. 1949, Mercer University; M.A. 1950, Northwestern University; LL.B. 1957, Mercer University; S.J.D. 1966, Harvard University. The author is a legal consultant to the ABA Commission on Evaluation of Professional Standards, but the opinions expressed herein are his own.

THE FOLLOWING CITATION WILL BE USED IN THIS ARTICLE:

ABA Code of Professional Responsibility (1978) [hereinafter cited as Code; Disciplinary Rules and Ethical Considerations therein hereinafter cited only by DR and EC numbers].

1. SEC v. National Student Marketing Corp. The litigation resulted in several reported opinions. See 360 F. Supp. 284 (D.D.C. 1973); 402 F. Supp. 641 (D.D.C. 1975); 68 F.R.D. 157 (D.D.C. 1975), affd, 538 F.2d 404 (D.C. Cir. 1976), cert. denied, 429 U.S. 1073 (1977); 430 F. Supp. 639 (D.D.C. 1977); 73 F.R.D. 444 (D.D.C. 1977); 457 F. Supp. 682 (D.D.C. 1978). Consent judgments were entered against various defendants at various times. See 457 F. Supp. at 687 n.2.

2. Lowenfels, Expanding Public Responsibilities of Securities Lawyers: An Analysis of the New Trend in Standards of Care and Priorities of Duties, 74 Colum. L. REv. 412, 421 (1974).

3. The lawyer owes "[e]ntire devotion to the interest of the client, warm zeal in the maintenance and defense of his rights, and the exertion of his utmost learning and ability, -these are the higher points, which can only satisfy the trnly conscientious practitioner." G. SHARSwOOD, AN Essay on Professional Ethics 78-80 (5th ed. Philadelphia 1884) (1st ed. Philadelphia 1854) (see note 14 infra). See Alabama State Bar Association Code of Legal Ethics Rule 10, $118 \mathrm{Ala}$. XXVI (1897). It is interesting to note that "[t]lhe SEC traditionally took the position that, while the securities lawyer had a duty to the investing public as well as to his client, his primary duty 
ethics, which deal with the duties to maintain the client's confidences and to avoid conflicts of interest. ${ }^{4}$ Whether this principle of loyalty developed as a result of these rules or vice versa, we cannot be sure. It is inost likely that the development of these ethical rules was originally justified by vague reference to the principle of loyalty to the client that only later took definitive form. This is at least a reasonable guess in light of Wigmore's account of the development of the attorney-client privilege. 5 In any case the chronology is not particularly important.

The important point is that the principle of loyalty and the rules it justifies are the product of three factors: the nature of the client, the role of the lawyer, and the legal process involved. In the adversary system of law administration, this naturally has meant that the rules of legal ethics have developed in response to the concerns generated by the lawyer, as advocate, representing an individual client in the judicial process. ${ }^{6}$

National Student Marketing posed a situation in which none of these factors was present. The lawyers were not properly viewed as advocates, the clients were not individuals in the common sense meaning of the term, and the process in question was not judicial. The law-

was owed to his client." Lowenfels, supra note 2, at 415 (citing American Finance Co., 40 S.E.C. 1043 (1962)). client).

4. See Code Canon 4 (confidences), Canon 5 (conflict of interest), and Canon 7 (loyalty to

5. According to Wigmore, the privilege evolved over a long period of time, having begun during the Elizabethan period as a privilege of the attorney. VIII J. WIGMORE, EvIDENCE $\$ 2290$ (3d ed. 1940). It was limited at first to confidences "given for the purpose of securing aid in litigation, and in the very litigation in which they were given." Id. $\$ 2294$ (emphasis in original). The first stage of expansion was the extension of the privilege to other litigation; then it was applied "to communications made in contemplation of a suit, or even after dispute had arisen though not directly with a view to litigation." Id. (emphasis in original) (footnotes omitted). It was finally extended to "communications made in seeking legal advice for any purpose . . . ." Id. (emphasis in original). This was the development of the privilege when it belonged to the lawyer; the privilege belonging to the client did not appear until the 1700 s. That privilege "co-exist[ed] with the older one for half a century," id. $\$ 2290$, and passed "more tardily through an independent though parallel development," until it was definitely recognized in its modern form in 1873 . Id. $\$ 2294$.

6. The single most influential writing on legal ethics in this country is probably Sharswood's Essay on Professional Ethics, first published in 1854, in which he writes, "The responsibilities, legal and moral, of the lawyer, arise from his relations to the court, to his professional brethren, and to his client." G. Sharswood, supra note 3, at 56. The following quote from Greenleaf's Evidence, in justification of the attorney-client privilege, is relevant to the point: "If such communications were not protected, no man ... would dare to consult a professional adviser, with a view to his defence, or to the enforcement of his right; and no man could safely come into a court, either to obtain redress, or to defend himself." I S. GREENLEAF, A TREATISE ON THE LAW OF EvideNCE $\S 238$ (Boston 1842) (footnote omitted). The emphasis on the lawyer as advocate, of course, is carried through in the Alabama Code of Legal Ethics of 1887, the ABA Canons of Professional Ethics of 1908, and, to a lesser extent, the ABA Code of Professional Responsibility of 1969. 
yers in the case represented two corporations, National Student Marketing Corporation (National Student) and Interstate National Corporation (Interstate), in a inerger transaction. The former was to be the surviving coinpany. Interstate's shareholders were to exchange their shares for approximately 1,650,000 shares of National Student stock. The proxy inaterial sent to solicit shareholder approval of the merger slowed that National Student would have a $\$ 700,000$ profit for a nine-month period deemed of special importance to the merger transaction. Just before the inerger was to be closed, however, National Student's accountants submitted a comfort letter to the lawyers for both companies that adjusted the company's earnings to show a net loss for that period rather than a $\$ 700,000$ profit. The lawyers declined to imsist that the contents of the letter be published or that Interstate's shareholders be resolicited. Rather, the lawyers proceeded to consummate the merger. ${ }^{7}$

This case is unique in our legal history in that the factors that shaped the rules of legal ethics were not present in their traditional form. Thus, the case can be distmguished, and if it were an isolated phenoinenon, it could be placed in its own pigeonhole to gather dust. Far froin being an isolated phenomenon, however, it is the most dramatic example of the current revolution in the law of legal ethics 8 to be found in our case law. It is a case mvolving the right elements in the right place at the right time, and it serves as an exemplar of the changes taking place. ${ }^{9}$ Part of National Student Marketing's significance lies in

7. SEC v. National Student Marketing Corp., 457 F. Supp. 682 (D.D.C. 1978).

8. Only the term "revolution" adequately characterizes the developments in the law of legal ethics in recent years, beginning with NAACP v. Button, 371 U.S. 415 (1963), and continuing through Brotherhood of R.R. Trainmen v. Virginia, 377 U.S. 1 (1964) (legal services); United Mine Workers v. lllinois State Bar Ass'n, 389 U.S. 217 (1967) (legal services); United Transp. Union v. State Bar, 401 U.S. 576 (1971) (legal services); Goldfarb v. Virginia State Bar, 421 U.S. 773 (1975) (minimum fee schedules); Bates v. State Bar of Arizona, 433 U.S. 350 (1977) (advertising); Ohralik v. Ohio State Bar Ass'n, 436 U.S. 447 (1978) (solicitation); and In re Primus, 436 U.S. 412 (1978) (solicitation). In recognition of these and other developments, ABA President William B. Spann in August 1977 appointed a Committee (later Commission) on Evaluation of Professional Standards to consider what changes should be inade in the ABA Code of Professional Responsibility adopted by the ABA House of Delegates only eight years earlier. See Patterson, Wanted: A New Code of Professional Responsibility, 63 A.B.A.J. 639 (1977).

9. The National Student Marketing case was not a matter of chance. According to public statements of various commissioners, the action was deliberately brought by the SEC to enlarge the responsibilities of securities lawyers. Thus, im a widely quoted speech, Commissioner A. A. Sommer, $\mathbf{J}_{\mathbf{r} . \text {, said: }}$

I would suggest that all the old verities and truisins about attorueys and their roles are in question and in jeopardy -and, unless you are ineradicably dedicated to the preservation of the past, that is not all bad.

I would suggest that im securities matters (other than those when advocacy is clearly proper) the attorney will have to function in a manner more akin to that of the auditor than to that of the advocate. 
the fact that it reveals one of the better kept secrets of the legal profession: the lawyer exercises an enormous amount of power under the guise of discretion to make decisions for the client, notwithstanding the fact that the client in theory retains the ultimate power of decision. Such a dramatic revelation of one of the mysteries of the profession will inevitably result in an increased dennand for lawyers to be held accountable for the exercise of this power, and thus the limits of the lawyer's discretion can no longer be measured solely by the principle of loyalty to the client.

In the past, the general proposition was that what the client wanted was what the client got, and the lawyer was comfortable in relying on the principle of loyalty to justify the exercise of whatever discretion the desires of the chent dictated. National Student Marketing demonstrates that efforts to limit the principle by rules requiring that the lawyer's loyalty, and thus his power of discretion, reinain within the liunits of the law have been less than wholly successful. Canon 7 of the Code of Professional Responsibility and the disciplinary rules thereunder notwithstanding, the probability that most lawyers still perceive the guiding principle to the exercise of discretion as loyalty to the client is very high. ${ }^{10}$

National Student Marketing thus runs counter to the unores of lawyers in the representation of clients, for it is based on the importance of the primciple of candor to the tribunal, rather than loyalty to the client. Most startling, perhaps, is that this decision implies that the principle of candor is co-equal with the principle of loyalty to the client in resolving cthical problems. Moreover, the case implies a primciple of fairness to opposing parties that also seems to rise to an equal status with the notion of loyalty to the client.

The notion that the propriety of a lawyer's conduct is to be determined by reference to co-equal principles of loyalty to the client, candor to the tribunal, and fairness to opposing parties represents a breakthrough in the law of legal ethics that will alınost inevitably reshape the lawyer's responsibilities. While most persons may perceive the developinent as a restriction of the lawyer's power of discretion, the result may well be to reshape and enlarge that power, for National Student Marketing means that the lawyer in the future must exercise a degree of client control that has heretofore been deeined wholly incon-

Sommer, The Emerging Responsibilities of the Securities Lawyer, [1973-74 Transfer Binder] FED. SEC. L. REP. (CCH) I 79,631, at 83,689. See Lowenfels, supra note 2, at 424-26.

10. The point is best demonstrated, perhaps, by the shock waves that the filing of the National Student Marketing complaint sent through the securities bar. See Hofiman, On Learning of a Corporate Client's Crime or Fraud-the Lawyer's Dilemma, 33 Bus. LAw. 1389, 1390 n.4 (1978). 
sistent with the duty of loyalty to the client." 11

This new perception of ethical priorities will in inany instances call for the exercise of discretion in exquisitely difficult situations, for as National Student Marketing inakes clear, rules of ethics are no longer interchangeable: the dictates of ethical rules will necessarily vary with the circuinstances of each situation. The measure of candor that is appropriate for the lawyer in the role of courtrooin advocate, for example, is not necessarily appropriate for the lawyer in the role of adviser to a chent seeking administrative agency approval for conduct that will affect thousands of inembers of the public.

Even though the rules are distinct for each situation, the principles froin which those rules are derived inust be constant. The lawyer must be loyal to the client im the administrative and private legal processes as well as in the judicial process. The principle of candor to the tribunal is relevant whether the lawyer is before a court, an administrative agency, or an arbitration panel. The principle of fairness to others, including the opposing party, is essential if we are to inaintain integrity in the administration of law.

The new approach to legal ethics presaged by National Student Marketing thus requires a rethinking of the limits on the lawyer's conduct and the law of legal ethics. The purpose here is to examine some propositions that may be relevant to the lawyer's exercise of discretion, propositions that are not necessarily new, but that may have a new meaning for the lawyer in light of current developments. The first proposition is that rules of ethics for the lawyer must be perceived as legal rather than moral, inandatory rather than discretionary. The second proposition is that the lawyer's rights and duties as lawyer when representing a client in relation to others are derivative: they are derived from the rights and duties of the client. The third and final proposition is that the limits of the lawyer's discretion in any particular case are determined by three factors: the nature of the client, the role of the lawyer, and the legal process involved.

11. See, e.g., Commissioner Sommer's speech in which he stated:

[The lawyer] will have to exercise a measure of independence that is perhaps uncomfortable if he is also the close counselor of management in other matters, often including busmess decisions. It means he will have to be acutely cognizant of his responsibility to the public who engage in securities transactions that would never have come about were it not for his professional presence.

Sommer, supra note 9, at 83,689-90. Contrast this view with a classic statement of the lawyer's duty of loyalty: "His loyalty runs to his client. He has no other master. . . . The lawyer's official duty, required of him indeed by the court, is to devote himself to the chient. The court comes second by the court's, that is the law's, own command." Curtis, The Ethics of Advocacy, 4 STAN. L. REv. 3, 3 (1951). 


\section{The Rules of Ethics as Rules of LaW}

Since the promulgation of the Code of Professional Responsibility in 1969 , the proposition that rules of ethics are legal, rather than merely moral, is no longer subject to much debate im theory. ${ }^{12}$ The notion that the rules are discretionary rather than mandatory dies hard, however. The implications of history, in the form of Hoffman's Fifty Resolutions of the 1830s, ${ }^{13}$ Sharswood's Essay on Professional Ethics of the 1850s, ${ }^{14}$ the Alabama Code of Legal Ethics of the 1880s, ${ }^{15}$ and the American Bar Association's Code of Professional Ethics of $1908,{ }^{16}$ are not to be so lightly swept away by a document of the 1960s. Some doubt as to the mandatory nature of ethical rules unquestionably remaims im the minds of most lawyers, a doubt that can have a debilitating effect at decision time. Only a firm conviction that the "rule" requiring conduct arguably contrary to human nature-such as a rule requiring a lawyer to inform on a chent with whom he has a fiduciary relationship-is law will suffice to secure the consistent compliance of most lawyers. Had the lawyers in National Student Marketing, for example, felt bound by DR 7-102(A)(3) ("In his representation of a client, a lawyer shall not: . . . (3) Conceal or knowingly fail to disclose that which he is required by law to reveal"), they would have saved themselves and their clients much trouble. The proposition that rules of ethics are indeed law, then, is worth examining.

Part of the problem in clearly perceiving ethical rules as legal rules is that we place too heavy a burden on the term "ethics" by failing to distimguish the types of conduct that are the proper subject of mandatory rules. Thus, problems of the lawyer's conduct that we freely characterize as unethical span a wide spectrum, ranging from major violations of criminal statutes to minor breaches of rules of etiquette. Such a cavalier characterization is mappropriate. The lawyer's violation of the criminal law is a breach of an ethical, professional duty in much the same way that murder is a tort; the term "unethical" is a

12. "The Disciplinary Rules, unlike the Ethical Considerations, are mandatory in character. The Disciplinary Rules state the minimum level of conduct below which no lawyer can fall without being subject to disciplinary action." CODE Preliminary Statement.

13. II D. Hoffman, A Course of Legal Study $752-75$ (2d ed. Baltimore 1836) (Ist ed. Baltimore 1817).

14. G. Sharswood, supra note 3. This work was originally published under the title "A Compend of Lectures on the Ains and Duties of the Profession of the Law, delivered before the Law Class of the University of Pennsylvania." The lectures were first given in 1854.

15. The Alabama Code of Ethics was written by Tloonas Goode Jones and first adopted by the Alabama Bar Association in 1887. See H. DRINker, Legal EThics 352 n.l (1953).

16. The Canons of Professional Ethics, adopted by the House of Delegates of the American Bar Association in 1908, were superseded by the Code of Professional Responsibility on January $1,1970$. 
very imprecise description of such conduct. The lawyer who embezzles a client's funds or aids a client in a scheme to bribe a public official is guilty of criminal conduct that raises no issues other than proof. Such probleuns can better be characterized as spurious ethical problems, thus avoiding any implication that they involve the lawyer's discretion. They are inatters to be dealt with legally but not to occupy inuch space in the law of legal ethics.

At the other end of the spectrum are rules of manners, which are more important than many may suppose. Courtesy is the balm that often serves to soothe the frictions of human intercourse. The slight that precludes a settlement can be expensive indeed. Rules of etiquette, however, are genume ethical rules only im the most subjective sense of the term, for maimers are not a matter of noral choice as unuch as they are a reflection of personality. ${ }^{17}$

If we leave aside those situations involvmg crimes and manners, there are two major kinds of ethical problems for the lawyer in the representation of a client: those that arise out of interaction between the lawyer and the client, and those that arise out of the lawyer's action for the client in relation to others.

Most of the ethical problems arising out of the lawyer's interaction with the client will not pose difficult problems. The lawyer has a duty to be competent ${ }^{18}$ and to keep the chent informed, and that is that. ${ }^{19}$ Rules involving these duties arise directly from the obhgations assumed by the lawyer in agreeing to represent the chent and are clearly proper subjects for rules of law. The chent's right to competent representation and the right to be informed, and the lawyer's correlative duties to be competent and to inform, are the ones least subject to compromise in the law of legal ethics.

The hard problems are those in the second category, those that result from the lawyer's action on behalf of the client in relation to others. These problems present a wide variety of difficult issues that range from the dramatic and tragic to the mundane and petty. In Spaulding v. Zimmerman, ${ }^{20}$ for example, a rather old case, the lawyer for the defendant in a tort action arising out of an automobile accident faced a dramatic problem. Exercising commendable caution, he had

17. Rules of professional etiquette may, of course, take on substantive aspects. The Federal Rules of Civil Procedure, for example, may be viewed as rules of professional etiquette for the conduct of litigation.

18. CoDE Canon 6 and DR 6-101.

19. Although the Code does not include a separate provision on the lawyer's duty of communication with the chent, the duty is obvious. It will be the subject of a separate rule in the document now being prepared by the Commission on the Evaluation of Professional Standards.

20. 263 Minn. 346, 116 N.W.2d 704 (1962). 
the plamtiff, a teen-age boy, exammed by a physician of his own choosmg. Despite the fact that the plaintiff had been examined twice by his own doctor, the defendant's physician discovered for the first time that the young man had an aorta aneurysm, probably caused by the accident. The lawyer's choice was either to inform the plaimtiff of the danger to his hife and thereby increase the cost of settlement to the client, or to keep quiet and save the client some money. He chose to keep quiet. In People v. Belge, ${ }^{21}$ a more recent case with truly tragic overtones, the lawyer representing a man charged with murder had, using information gained from his client, sought and found the hidden body of the young woman his client had killed. When the victim's father asked the lawyer for imformation about his missing daughter's whereabouts, the lawyer declined to answer. On a more mundane level, im Halloran $v$. Blue \& White Liberty Cab Co., ${ }^{22}$ plamtiff's lawyer in a tort action, thinking the defendant's busimess was incorporated, misnamed the defendant as a corporation. His opponent answered the complaint with a negative prcgnant, thereby winning the case, if only temporarily. ${ }^{23} \mathrm{On}$ perhaps the most petty level, lawyers engage in widespread abuse of discovery, including "the well-known tactic of producing volumes of documents in studied chaos, either to burden the opposition or to increase the possibility that a significant document will be overlooked between the helter and the skelter."24 Does a lawyer have a duty to turn over to the prosecutor real evidence of the client's guilt obtamed from a third party?25 Does the lawyer for the vendor of realty have a duty to tell the vendee that his client is imcompetent, and thus that the transaction can be voided? ${ }^{26}$

If the practitioner views rules of ethics as moral rules rather than legal rules, he perceives such problems as dileminas. If the problem is a dilemma he has discretion im solving it, and he may choose to do so by means of an undesirable course of conduct. In fact, the duty of loyalty to the chent encourages him to choose the undesirable course of conduct if it might benefit the client. Thus, in the Spaulding case, the lawyer chose to conceal life-tlureatening information because to reveal

21. 50 App. Div. 2d 1088, 376 N.Y.S.2d 771 (1975), affd, 41 N.Y.2d 60, 359 N.E.2d 377, 390 N.Y.S.2d 867 (1976). For background on this case, see Comment, Legal Ethics: Confidentiality and the Case of Robert Garrow's Lawyers, 25 Buffalo L. Rev. 211 (1975).

22. 253 Minn. 436,92 N.w.2d 794 (1958).

23. The case, involving approximately $\$ 1,000$, was before the municipal court of Minneapolis four times and the Minnesota Supreme Court twice over a five-year period. 253 Minn. at 437; 92 N.W.2d at 795 .

24. Umin, Discovery Reform: A New Era or Business as Usual?, 65 A.B.A.J. 1050, 1052 (1979).

25. See Morrell v. State, 575 P.2d 1200 (Alaska 1978).

26. See Goerke v. Vojvodich, 67 Wis. 2d 102, 226 N.W.2d 211 (1975). 
it might have cost the chent some money. Yet, at the time of the Spaulding case, Canon 22 of the Code of Professional Ethics provided, "[T]he conduct of the lawyer before the Court and with other lawyers should be characterized by candor and fairness." 27 On the other hand, the lawyer in the Belge case perceived his obligation to maintain silence as mandatory ratlier than discretionary, for he was not relying on an ethical "rule," but rather on the attorney-chent privilege, clearly a rule of law. While the result of this perception was undoubtedly distasteful, it was one unandated by law rather than encouraged by a desire to benefit the client. It poses, therefore, a "dilemma" clearly distinguishable from that presented by the Spaulding case. In the Halloran case, an inadequate perception of the legal quality of ethical rules is again apparent as the lawyer in that case chose to take advantage of his opponent's mistake even though it meant misleading the court and abusing the judicial process in violation of then applicable Canon 22.

The difficulty that the lawyers faced in the Spaulding and Halloran cases was that they beheved they had no defimitive rules of law to guide them. In both instances they inade the wrong decision, one that cost their clients both time and money in more hitigation and in final judgment. The situation in the Belge case was different, and the lawyer's decision not to reveal the information could be said to be correct in that it was sustamed.28 The more interesting point, however, is that all three cases involved essentially the same problem that the lawyer faced in National Student Marketing: the problein of communicating information detrimental to the chent. Indeed, it is this issue that is almost invariably at the heart of those ethical problems arising when the lawyer is acting for the client in relation to another. Witlout the coinmandment of a legal, as opposed to an "ethical," rule, the lawyer is going to find it inordinately difficult to convey this kind of information to another. The extent of this difficulty is unade apparent by a reading of Canon 4 of the Code of Professional Responsibihty. ${ }^{29}$

To recognize rules of legal etlics as rules of law, however, is not sufficient. No matter low niany ethical rules are niade niandatory, the

27. aba Canons of Professional Ethics No. 22.

28. It is interesting to note that, despite its affirmance of the lower court's holding, the court felt compelled to state: "We believe that an attorney inust protect his client's interests, but also must observe basic human standards of decency, having due regard to the need that the legal system accord justice to the interests of society aud its individual members." 50 App. Div. 2d at 1088, 376 N.Y.S.2d at 772.

29. DR 4-101(C), for example, provides: "A lawyer may reveal: . . . (3) The intention of his client to coununit a crime and the information necessary to prevent the crime." The problem is the permissive "may." The inteut behind the provision apparently is to relieve the lawyer of the fear of professional sanction if he does reveal the information in these circumstauces. This interpretatiou, however, still leaves the lawyer with the discretion not to reveal. 
lawyer will still have to exercise discretion in the representation of a client, for his basic function is to individualize the law for his client. To exercise his discretion wisely, he must understand the limits of that discretion. Helpful, if not essential, to this effort is an understanding of the derivative nature of his rights and duties as a lawyer.

\section{The Derivative Nature of the Lawyer's Rights and DUTIES}

The climax in the National Student Marketing scenario was the accountant's decision that the information showing a $\$ 700,000$ profit sent to the shareholders of both compames to secure approval of the proposed merger was a mistake, and that instead the information should have shown a loss for the period in question. Despite the potentially critical inportance of this information, disclosure was avoided and the merger completed on the basis of maccurate financial data.

In retrospect, this was a mistake, and the question is not where, but why, the lawyers went wrong. Since the client did not have a right to proceed in violation of the law, a reasonable guess is that the lawyers failed to recognize that their rights and duties in acting for the clients were derivative in nature, being dependent upon the rights and duties of their clients. The proposition is one that is obvious on reflection, but it is not one that has been given much thought.

The result in almost any case involving the propriety of a lawyer's conduct in acting for a client turns on whether the lawyer was exercising a right of the client. Thus, in the Spaulding case discussed above, the ultimate issue was whether the lawyer's client had a right to a court approved settlement without revealing the information about the plaintiff's aorta aneurysm. In the Halloran case, the issue was whether the lawyer's client had a right that the lawyer respond to the coinplaint with a negative pregnant, and in the Belge case, the issue was whether the client had a right that the lawyer keep his confidences.

The list could be extended indefinitely, particularly with cases involving the attorney-client privilege, for this is one area in which the proposition is manifest. The privilege belongs to the client, not to the lawyer..$^{30}$ The lawyer's right not to reveal under legal compulsion is derived from the client's right not to reveal. The inore interesting question, however, is why this awareness of the derivative nature of a lawyer's rights and duties has not been applied im analyzing other aspects of the lawyer's conduct.

The answer must be that the notion of loyalty to the client has

30. See note 5 supra. 
been presumed to be the primary principle limiting the lawyer's conduct. The lawyer's relationship with the client has been deemed to be the deterinining factor in ethically perplexing situations. However, if we accept the proposition that the lawyer's conduct is guided by three principles-candor and fairness as well as loyalty-it then becoines clear that the lawyer has three, rather than one, relationships witli which to be concerned: the determining factors include his relationships with the tribunal and with the opposing party as well as with the client. This would seem to mean that the lawyer's duties result in conflicting rights for him. Thus, if the lawyer has a duty of loyalty to the client, he seeiningly has a right to be loyal to the client in preference to his duty of candor to the tribunal. Similarly, his duty of candor to the tribunal appears to give him a right to be candid to the tribunal in preference to his duty of loyalty to the client. The same follows froin his duty of fairness to the opposing party, which seeins to imply that he has a riglit to exercise sucli fairness in preference to his duty of loyalty to the client and his duty of candor to the tribunal.

This is confusion coinpounded, indicating that something is amiss. What happens to the proposition that the lawyer is a representative of the client wliose primary duty is to protect the client's rights? The key here is the phrase, "the client's rights." The fault of the above analysis is the assumption that we are talking about tlie lawyer's rights and duties as if they were independent of the client's rights and duties. The fact is that the lawyer acts in a representative capacity-as an agent, not as a principal - and that the rights and duties involved belong to the principal rather than to the agent. Thus, when the lawyer is acting for the client, his rights and duties in relations with others are derivative in that they are derived froin the rights and duties of the client.

The fact that the lawyer's rights and duties are derivative does not necessarily provide answers. The difficulty is that the rights and duties of the client are not always clear. There may be no rules of law defining those rights and duties in a given situation, or if such laws do exist, they nay be annbiguous or even in conflict. If the latter situation is the case, it is the lawyer's job to interpret those legal rules and to harness the disorderly conduct of the relevant words. This undertaking, as well as deciding in the absence of rules, calls for the exercise of properly limited discretion.

\section{The Limits OF THe LAWYeR's Discretron}

Discretion is the right to act autononnously within defined constraints. The constramts are not always clearly defined, lowever, and when this is the case, ascertaining the limits of the lawyer's discretion 
involves two inquiries: What is the normal range of conduct permissible, and to what extent inay, or should, the lawyer vary from that normal range of conduct?

A resolution of the first inquiry, even if wrong, obviates the necessity of addressing the second. One can assuine, for exainple, that the lawyers in National Student Marketing perceived their conduct in proceeding with the merger as within the normal range of constramts, which they no doubt ineasured in terms of loyalty to the client. They were wrong. They did not realize their error, however, and thus did not reach the second issue to ascertain whether there was a basis for varying from the norm. The same is true of the Spaulding case, in which there was in fact a basis for varying from the normal conduct of not providing information gratuitously to the adversary. That basis, of course, was the fact that the information might have saved the adversary's life.

The range of normal conduct is determined in the first instance by the law defining the rights and duties of the client. Due to the lack of absolute certainty in the law, however, the rights and duties of the client are sometimes determined by factors other than rules of law. ${ }^{31}$ This is the lesson of EC 7-11 of the Code of Professional Responsibility, which reads:

The responsibilities of a lawyer may vary according to the intelligence, experience, mental condition or age of a client, the obligation of a public officer, or the nature of a particular proceeding. Examples include the representation of an illiterate or an incompetent, service as a public prosecutor or other government lawyer, and appearance before administrative and legislative bodies. ${ }^{32}$

As this language indicates, there are three factors other than the words of any rule that are relevant in determining the rights of the client and thus the constraints in the lawyer's discretion: the nature of the client, the role of the lawyer, and the legal process involved.

31. Rules of law, of necessity, are general and thus cannot always be properly applied even if the words of the law appear to dictate otherwise. This, of course, explains why the law contains so many exceptions to the rules. Consider the rule that an agreeinent purporting to release a party from liability procured by fraud may be set aside only if the consideration is tendered or returned. In dealing with this issue, one court concluded:

A release procured by fraud will be set aside, without tender or return of the consideration, when the releasor, because of conditions of poverty, is unable to ineet the tender-orreturn requirement and the fraud remamed undiscovered until after the consideration had been expended or otherwise pnt beyond the releasor's control.

Vickers v. Gifford-Hill \& Co., 534 F.2d 1311, 1314 (8th Cir. 1976).

32. See also EC 7-12: "Any mental or physical condition of a client that renders him incapable of making a considered judgment on his own behalf casts additional responsibilities upon his lawyer." 


\section{A. The Relevance of the Nature of the Client.}

The lawyer's first and foremost concern is the imterest of the chent, and it is a truism that different chents have different interests. But we can go further and say that different chents in similar situations have different rights. The minor who enters into a contract, for example, has different rights from an adult who enters into a similar contract. Throughout the course of Anglo-American history, the law has distmguished persons in terms of legal rights and duties; these distinctions are based on biological, economic, and sociological differences and generally recognize conditions requiring legal rights beyond those accorded the more fortunate.

To the extent that the positive law makes these distinctions, they should present no problems for legal ethics; however, the rules of legal ethics do not for the inost part take the distimctions into account. The paradigm of the client im the Code of Professional Responsibility is the mature, competent, and self-sufficient adult, and it is only in the ethical considerations, not the disciplinary rules, that there is any suggestion of a distinction. ${ }^{33}$

There seen to be two reasons for this. One is that the law of legal ethics is procedural, and it is procedural in a unique way. The lawyer in actimg for the client exercises, and can exercise, only procedural rights of a chent. He cannot, by definition, exercise the client's substantive rights, unless, of course, the chent gives him a power of attorney. Whatever differences there may be im substantive rights, the uniformly held presumption is that procedural rights must be uniform.

The second reason is that the lawyer is concerned with securing and protecting the substantive rights of his client, and those rights, he assuines, are determined only by rules of law. It is this assumption that shaped the present Code of Professional Responsibility. But all rules of law contam implicit limitations and extensions and are subject to interpretation. Thus, the rights that a particular rule of law entails depend upon the context in which the rule is applied, and the context always includes the nature of the adversary. Consequently, the rights of one's client may be limited by the rights of the party with whom the chient deals, despite the wording of a particular rule. The Code of Professional Responsibility is $\mathrm{m}$ error for failing to provide for this in its proscriptions.

The adversary system inilitates against this position, for the correlative duties it imposes relnove the rationalization for the lawyer in pre-

33. EC 7-11 and EC 7-12 are not reflected in the Disciplinary Rules of Canon 7. 
paring one-sided adhesion contracts, ${ }^{34}$ utilizing cognovit notes, ${ }^{35}$ and misusing jurisdictional statutes, ${ }^{36}$ to say nothing of refusing to correct misleading proxy material. Nevertheless, the point is useful im distinguishing the norinal constraints on the lawyer's conduct and the permissible variations from those constramts in the exercise of the lawyer's discretion. The normal constraints are generally determined by the legal rights of the client as defined by substantive law; permissible variations from those constraints are determined by variations allowed under substantive law based on the nature of the chent. Variations in substantive law nccessarily include consideration of the nature of the person with whom the chent is dealing.

The nature of the client thus has a direct relevance to the lawyer's exercise of discretion. For that reason, it is helpful to categorize the types of clients a lawyer may serve and to indicate briefly how, as their character changes, the lawyer's ethical decisionmaking takes on different dinensions. Apart froin the inature, competent, and self-sufficient adult, there seem to be three categories of chents whose representation inay create issues as to the scope of the lawyer's exercise of discretion, justifying at times variation from the normal range of conduct. These are the accused, the aberrant, and the artificial client.

The accused client-one charged with committing a crime-is a special type of chent who is given many special rights not accorded civil clients. Such rights as the right against self-incrimination, the right to testify, the right to counsel, and the right to confront one's accuser are called into play. There are times when the existence of these constitutional rights places the lawyer in a quandary as to what he may or should do, for example, in the case of chent perjury. The question posed by the prospect of chent perjury is not whether constitutional rights should prevail over statutory duties-e.g., whether the right to counsel should prevail over the duty to testify truthfully-but rather what the constitutional right actually entails. Must, or may, a lawyer inforn the court of the accused client's perjury? The question is not made easier by its proper identification, and it is one to which different courts have given different answers. ${ }^{37}$ This dilemma illustrates how the

34. See, e.g., Hy-Grade Oil Co. v. New Jersey Bank, 138 N.J. Super. 112, 350 A.2d 279 (App. Div. 1975).

35. See, e.g., D.H. Overmeyer Co. v. Frick Co., 405 U.S. 174 (1972); Swarb v. Lennox, 405 U.S. 191 (1972).

36. See, e.g., Tickle v. Barton, 142 W. Va. 188, 95 S.E.2d 427 (1956).

37. Compare McKissick v. United States, 398 F.2d 342 (5th Cir. 1968) and State v. Henderson, 205 Kan. 231, 468 P.2d 136 (1970) with Lowery v. Cardwell, 575 F.2d 727 (9th Cir. 1978). See also Unitcd States v. Grayson, 438 U.S. 41 (1978); People v. Longuemire, 87 Mich. App. 395, 275 N.W.2d 12 (1979). 
nature of the client may influence a lawyer's ethical decisionmaking, the factors relevant to that process being dictated purely by the umique considerations pertaining to the criminally accused client.

Aberrant clients, the second category, are those under a disability-e.g., the poor, the illiterate, minors, the mentally ill-whose disability distimguishes them sigmificantly from the competent adult client that is the nodel for the Code of Professional Responsibility. If he is to represent such clients competently, the lawyer must have the discretion to vary froin the normal range of permissible conduct. There may, for example, be occasions in which the lawyer must breach the client's confidences, not only to protect the client but to protect others as well. The lawyer whose client confesses to arson and confirms that he is a pyroinaniac should not be precluded by the attorney-client privilege froin providing that client with help.

Of all the categories of clients, the one that presents the most complex problems is the artificial chent, the legal entity. The traditional notion is that the legal entity is itself tlie client, ${ }^{38}$ but it is surely conceptually difficult for a lawyer to consider a legal fiction as his client. Rather, the lawyer for a corporation probably perceives the chief executive officer as his client and thus disregards the legal fiction. He may do so at his peril, as National Student Marketing suggests, for the fact is that the lawyer must serve the interests of the corporation.

When a lawyer is serving a legal entity, his duties and the proper measure of his discretion vary in one major respect from when he is representing a luman client. When the lawyer is representing an individual, the relationship is usually viewed as one of agency, with the lawyer as the agent and the client as the primcipal who has the ultimate power of decision. Formally, the relationship seems identical when the lawyer represents an entity, but practically, when the client is a legal entity, the client cannot exercise the power of decision; it can only decide through agents. Thus in this situation the lawyer is an agent of a client, but an agent who can deal only with other agents of the client. Both the lawyer and the officers are agents of the corporation, and both have fiduciary duties to the corporation.

The lawyer's relationship with corporate officials is a relationship with them in their official, not their personal, capacities. In a sense the corporate officials are derivative clients of the lawyer, smce their entitlement to the lawyer's services is derived from their corporate posi-

38. "A lawyer employed or retained by a corporation or similar entity owes his allegiance to the entity and not to a stockholder, director, officer, employee, representative, or other person connected with the entity." EC 5-18. 
tions. ${ }^{39}$ This means that the lawyer's duties to the corporate officials are determined by the officials' rights and duties as officials.

In the representation of a corporation, then, the lawyer has duties to the corporation imdependent of those to the corporate officials. This is one of the lessons of National Student Marketing. What those duties are and how they comport with the lawyer's duties to corporate stockholders, officials, and employees is a matter of law. The crucial point is that the individuals composing the corporate entity-the stockholders, the directors, and the officers-are governed by two bodies of law, the general law applicable to all and the special law applicable to thein in their corporate capacities. It is this special law that gives the lawyer the discretion, indeed the duty, to vary his conduct when necessary from that whicl is appropriate when the client is an individual.

\section{B. The Relevance of the Role of the Lawyer.}

The National Student Marketing case, by dealing with the lawyer's traditional role of adviser in a nontraditional way, suggests that the particular role of the lawyer is relevant in determining the limits of the lawyer's discretion. The role of the lawyer reflects the extent to whicls the client has delegated the care of his rights to the lawyer and is thus a measure of the lawyer's responsibilities. The problem is that courts have difficulty characterizing the roles of the lawyer beyond those of adviser and advocate. Diversified Industries, Inc. v. Meredith ${ }^{40}$ is a case in point.

In Diversified, plamtiff Diversified, having learned of the possibility of misconduct on the part of its employees, asked the law firm of Wilner, Cutler \& Pickering to inake an imvestigation and to report its

39. The term "derivative client" has been used to describe the situation in which two persons other than the lawyer are involved. See, e.g., In re Dolan, 76 N.J. 1, 384 A.2d 1076 (1978):

The derivative client is the chent whose representation by the attorney derives from his participation in a transaction with the party who is the primary client of the attorney. The derivative client is the chient to whom disclosure is made and from whom consent to the dual representation is sought.

Id. at 14 n.I, 384 A.2d at 1082 n.l (Pashman, J., concurring in part and dissenting in part). Except for the requirement of consent, a similar analysis would seem to apply when a corporate entity is the client.

An analogous problem is that of a lawyer representing a trustee.

As a representative for the beneficiaries of the trust which he is administering, the trustee is not the real client in the sense that he is personally being served. And, the beneficiaries are not simply incidental beneficiaries who chance to gain from the professional services rendered .... The trustees here cannot subordinate the fiduciary obligations owed to the beneficiaries to their own private imterests under the guise of attorney-client privilege .... In effect, the beneficiaries were the chents of Mr. Workman [the attorney] as much as the trustees were, and perhaps more so.

Riggs Nat'l Bank v. Zimmer, 355 A.2d 709, $713-14$ (Del. Ch. 1976) (emphasis in original). 40. 572 F.2d 596 (8th Cir. 1977), rehearing en banc, 572 F.2d 606 (8th Cir. 1978). 
finding to the Board of Directors. The concern was for a slush fund possibly used to bribe einployees of custorners, one of whom was the Weatherhead Company which subsequently brought an action against Diversified. In its action, Weatherhead sought to obtam the reports Wilmer, Cutler \& Pickering made to the Board, a nove that Diversified resisted, even to the point of seeking a writ of mandamus to overturn a district court order allowing discovery. The issue was whether the imformation fell within the lawyer-chent privilege, and it turned upon the existence of a lawyer-client relationship between the law firm and Diversified. A sliarply divided three-judge panel held that there was no lawyer-client relationship; on the en banc rehearing, this ruling was reversed, agam with a strong dissent. The issue turned on the role of the law firn. Were the lawyers of the firm rendering legal services, or were they acting merely as investigators in a nonprofessional capacity?

The majority opinion on the en banc reliearing stated: "Here, the inatter was committed to Wilmer, Cutler \& Pickering, a professional legal adviser. Thus, it was prima facie committed for the sake of legal advice and was, therefore, within the privilege absent a clear showing to the contrary." 41 The dissenting judge concluded: "I am satisfied that Law Firm was not einployed to provide legal services or advice. It was employed to make a factual investigation and busimess recommendations in such areas as the results of the investigation might suggest. And Law Firn did just that." 42

The lawyer in Diversified obviously was not an advocate, and the efforts of the court to characterize his role as that of adviser indicates the influence the traditional roles of adviser and advocate contimue to have on the thinking of judges. In fact, the lawyer has long perforined other roles for the client. Thus lawyers have served not only as investigators or legal auditors ${ }^{43}$ for their clients, but also as negotiators in business deals, ${ }^{44}$ mterinediators im resolving disputes between chents, ${ }^{45}$ and private legislators in draftimg legal documents. ${ }^{46}$ Cases mvolving these varied roles, however, have almost always involved the applicability of the attorney-client privilege, and courts have based their deci-

41. 572 F.2d at 610 .

42. Id. at 614 (Henley, J., concurring in part and dissenting in part).

43. See, e.g., Metalsalts Corp. v. Weiss, 76 N.J. Super. 291, 184 A.2d 435 (Ch. Div. 1962).

44. See, e.g., Coinınercio E Industria Continental, S.A. v. Dresser Indus., 19 F.R.D. 513 (S.D.N.Y. 1956).

45. See, e.g., Kleının v. Superior Court, 75 Cal. App. 3d 893, 142 Cal. Rptr. 509 (1977) (lawyer permitted to represent both parties in an uncontested divorce); $c f$. Ishinael v. Millington, 241 Cal. App. 2d 570, 50 Cal. Rptr. 592 (1966) (lawyer acted for wife at request of husband in divorce action and was held liable to wife for not protecting her interests).

46. See, e.g., Heyer v. Flaig, 70 Cal. 2d 223, 449 P.2d 161, 74 Cal. Rptr. 225 (1969) (en banc). 
sions solely on whether the lawyer was also acting as legal adviser. If he was, the privilege applies; otherwise the privilege may not be asserted.

Regardless of the policy considerations as to the applicability of the attorney-client privilege, loldings based on such a narrow ground are disturbing and possibly inischievous. They imply that the lawyerclient relationship is a unitary one, and they give rise to significant questions regarding the implications of this narrow view for the rules of confidentiality and conflicts of interest generally. If the dissent in the Diversified case, for example, had prevailed, would Wilmer, Cutler \& Pickering be precluded from suing Diversified for anotlier client in a related matter? If a lawyer who negotiates a business agreement for a client is held not to be acting as a lawyer, may lie then sue the former client for a breach of the resultimg contract? To ask these questions is to answer them, for even if the lawyer does not act as legal adviser or advocate, the fact is that these relationships involve a significant interaction between the lawyer and the client.

The problem is thus one of more than theoretical interest; as the disparate roles of the lawyer beconve increasingly identified and recognized, they will becoine increasingly important as a factor in measurimg the lawyer's exercise of discretion, both for the lawyer and for the court. Consequently, it inay be lielpful to re-examine the nature of the lawyer-client relationship in hight of these roles.

The traditional characterization of the relationship of the lawyer and client as one of agency, witl the client as the primcipal and the lawyer as the agent, is sound as a general proposition. It is, lowever, too simplistic; different roles of the lawyer make the agency designation alone inadequate. When the lawyer acts as legal adviser, for example, he is more like an independent contractor than an agent. He does not act for the client in relation to others, but deals directly with him. This distinction has important implications, providing as it does a separate basis of responsibility for the lawyer. The hability of the lawyers in National Student Marketing, for exainple, was based on the fact that their role gave thein independent responsibility for their actions separate and apart from the wishes of the client. The other side of the coin is that the designation inay be important to the client if, for example, there is a question of vicarious liability involved. Is the client liable on the basis of the doctrime of respondeat superior for the lawyer's defamatory statements inade about the plaintiff im advising the client? At least one case has lield that the client is not liable, because the lawyer's role 
in advising the client was that of independent contractor. ${ }^{47}$

When the lawyer acts as advocate, he is an agent of the client, but he is a special agent for a limited purpose ${ }^{48}$ who is not wholly subject to the will of the client. As to tactical inatters in a trial, for exainple, the lawyer, not the client, has the right to make the decisions. ${ }^{49}$ Moreover, as an officer of the court, the lawyer has duties to others than the chent: the duty of candor to the tribunal and of fairness to the adversary.

The nontraditional roles result in a different kind of relationship that more nearly coinports with the term "agent." As negotiator, the lawyer fulfills all of the requisites of an agent since he is in effect a surrogate for the chent. When the lawyer acts as an investigator or legal auditor, an intermediator, or a private legislator, however, his position takes on unany of the characteristics of an independent contractor. Even so, the client in these situations retams the ultimate power of decision; the lawyer's rights and duties in these roles are nore directly derivative of the client's rights and duties than those assumed in the lawyer's role as adviser or advocate. Although the word "attorney" carries inuch excess baggage, it is the inost useful term to designate these roles: an attorney is "an agent or substitute, or one who is appointed or authorized to act in the place or stead of another."50 The word, lowever, has become too well identified as a synonyin for lawyer. The term "agent" in the sense of legal agent may thus be the inost appropriate, if not the inost accurate, term to designate the capacity of the lawyer in these roles. The term "agent" does serve to distinguish the lawyer in fulfilling these functions froin the lawyer as adviser or advocate. More importantly, it provides the courts with a basis for avoiding the fiction that no lawyer-client relationship exists in these situations.

Distinctions between the various roles of the lawyer are to some extent artificial. Occasionally the roles exist in isolation, ${ }^{51}$ but in most cases the lawyer will serve the chent as advisor and legal agent in various capacities, and as advocate as well. To reject the significance of distinguishing the roles on this ground is to miss an important point, however: while the lawyer may serve in all the roles for a single client

47. Williams v. Burns, 463 F. Supp. 1278 (D. Colo. 1979).

48. "The attorney [as advocate] is in effect a special agent limited in duty to the vigilant prosecution and defense of the rights of the client and not to bargain or contract them away." Northwest Realty Co. v. Perez, 80 S.D. 62, 65, 119 N.W.2d 114, 116 (1963).

49. Stricklan v. Koella, 546 S.W.2d 810 (Tenn. App. 1976).

50. Black's Law Dictionary 117 (5th ed. 1979).

51. See, e.g., Diversified Indus., Inc. v. Meredith, 572 F.2d 596 (8th Cir. 1977) (investigator); Phillips v. Delaware Power \& Light Co., 194 A.2d 690 (Del. Super. Ct. 1963) (adviser); Metalsalts Corp. v. Weiss, 76 N.J. Super. 291, 184 A.2d 435 (Ch. Div. 1962) (investigator). 
at one time or another, he does not do so at the same time. Thus, the important issue is the identification of the role played by the lawyer at the time of the conduct in question. There is, for example, a significant question whether a lawyer serving as courtroom advocate for an accused client should reveal the client's perjured testimony to the court, thus precludimg its admission into evidence; there is no question whether the lawyer, acting as pre-trial adviser, may advise his chent to commit perjury.

\section{The Relevance of the Legal Process.}

The legal process in which the lawyer is engaged plays a significant role im determining the outer constraints of the lawyer's power of discretion. In the administrative process, for example, the lawyer inay have to provide information detrimental to the chent that he would not have to provide in the judicial process. Deciding what is proper in each instance will certainly not be easy. An adequate test to determine the appropriateness of lawyer conduct would seem to be whether, given the functional purpose of the process involved, the proposed conduct will corrupt the integrity of that process. The result in National Student Marketing would appear to support the use of such a test. The conduct of the lawyers in that case clearly violated the integrity of the administrative procedures of the Securities and Exchange Commission. As a result, the lawyers' conduct was properly condemned.

The major ethical problem in relation to each legal process is that of the lawyer's candor; the difficulty is in determining the limits of the lawyer's duty to tell the truth. The key here is the concept of reliance. In each of the legal processes with which the lawyer is concerned, a different degree of rehance upon the lawyer's candor is reasonable. The administrative process, for exainple, is a loosely structured, dutyoriented process established for the purpose of administering law for the benefit and protection of the public. In contrast, the judicial process is a highly structured, rights-oriented process designed to provide persons an institutional setting to resolve their disputes. The private legal process, in further contrast, is an unstructured process that enables citizens to make their own law, resolve their own disputes, and give order to their private affairs without governmental intervention.

The notions of evidence and proof may be used to determine the degree of candor appropriate to each of these three processes. Evidence is a proposition of fact in partial support of a conclusion; proof is a proposition in complete support of a conclusion. A proposition of evidence, then, is ineant to induce partial rehance; it is to be considered along with other propositions in determining the proper conclusion. A 
proposition of proof, on the other hand, is in the form of the conclusion itself and is intended to induce complete reliance. In the administrative process, the information the lawyer presents to the agency takes the form of proof, and the administrator must be able to rely on it. ${ }^{52}$ If, for example, the lawyer for a client in the offering of securities gives an opinion letter that the law has been fully complied with, the administrator must be able to rely upon that letter as proof of the matter stated therein.

The judicial process presents an entirely different context. In this setting the lawyer presents evidence, as opposed to proof, through the agency of witnesses. Moreover, he presents evidence to a dismterested trier of fact who will hear both sides of the issues, in accordance with a large body of procedural rules. Furthermore, the evidence is subject to testing by an adversary. As Professor Elliott Cheatham once said, the lawyer in a trial has a duty to tell the truth and nothing but the truth, but he need not tell the whole truth. ${ }^{53}$

The private legal process is both unique and comprehensive. It is unique because it involves the delegation of a large amount of legal power to private citizens. It is comprehensive because it imvolves aspects of the administrative, the judicial, and the legislative processes. Whereas the imstitutions of the public legal processes are the administrative agency, the court, and the legislature, the institution of the private legal process is the law office.

On balance, the private legal process is more analogous to the administrative process than to the judicial process in terms of legal ethics, since the integrity of the private legal process is almost wholly dependent upon the integrity of the individual lawyer. The variety of the lawyer's tasks im the private legal process amply illustrates the sigmifcance of the notion of rehance $\mathrm{m}$ assessing the dimensions of a lawyer's ethical decisionmaking. Indeed, the jobs undertaken by an attorney within the private legal system compel us to look almost wholly to the concept of reliance to determine the limits of the lawyer's duty to tell the truth. In negotiating a settlement or a contract, for example, puffing is the rule rather than the exception. The question in determining the propriety of lawyer conduct is whether a statement is intended to serve the purpose of proof in inducing reliance. It is one thing to char-

52. Kingsland v. Dorsey, 338 U.S. 318 (1949).

53. L. Patterson \& E. Cheatham, The Profession of Law 86 (1971). Two caveats are in order. One is that the lawyer cannot present a proposition of evidence he knows to be false. The other is that the reasoning as to evidence does not apply to law. In citing cases and statutes to the judge, the lawyer is presenting propositions in the form of proof to induce complete rehance, and coinplete candor is required. 
acterize an offer as final; it is another to give a false statement as to the amount of acreage the property contams. The former statement is clearly recognizable as a negotiating ploy; the latter is a falsehood regarding an essential element of the agreement.

In dealing with the legal processes, however, there is an important qualification. The administrative process mcludes judicial-type proceedimgs, the judicial process includes administrative components, and the private legal process includes both administrative and judicial characteristics. The workmen's compensation hearing, for example, nominally admimistrative in nature, is judicial in function; the uncontested divorce and the probate of a will, nominally judicial in nature, are in fact administrative. Even the ex parte hearing, an integral part of the judicial process, is administrative in nature: it is only ancillary to hitigation, with the lawyer presenting his petition as proof to induce reliance by the judge without a presentation from an adversary. Even in the private legal process, there are arbitration hearings, judicial in nature; when a private attorney serves as the trustee of a trust, he is engaged in an administrative task. Thus, it is important when using the legal process as a measure of the lawyer's discretion to view the particular proceeding in functional rather than nominative terms.

\section{The Need for Greater Flexibility.}

Recognition that the nature of the client, the roles of the lawyer, and the legal process involved are relevant to the lawyer's exercise of discretion provides greater flexibility in the law of legal ethics. The flexibility is needed for lawyers engaged in the inordmately complex task of administering law for clients under the triple burden of duties to the tribunal and the adversary as well as to the chent. At the same time, recognition of the importance of the three factors also provides the lawyer with more precise measures for determining the limits of his discretion.

The three factors are always present and relevant, but they are not determinative in every case. The normal adult chent with an ordmary legal problem presents the situation in which recourse to an analysis of these factors is generally superfluous, as the problem can usually be taken care of within the norinal constraints of the lawyer's exercise of discretion. It is in the unusual situation that it is necessary to go beyond the normal constraints and to search for the implications of each of these factors. A simple example of such a situation is when the lawyer acquires information about an adversary in hitigation that is detrimental to his client but that may save the adversary's hife.

What is clear from an analysis of any ethically perplexing circum- 
stance that a lawyer may face, beyond those matters that have been referred to here, is that the rigidity of our shared perspective on legal ethics is a severe detriment to adequate ethical decisionmaking. The lack of flexibility im the law of legal ethics, a product of the notion that ethical rules are fungible, means that the lawyer tends to deal with the extraordinary situation in terms of the rules applicable to the ordimary situation. He does keep the information about the adversary's condition to himself, even though disclosure could mean saving a boy's life. Not appreciatimg the nature of the restraints on his discretion, he keeps quiet and proceeds in the normal manner in this abnormal situation. This above all else appears to be the central characteristic of our decidedly inadequate ethical thinking.

This shortcommg almost certainly was the basis of the problem in National Student Marketing. The lawyers were not conscious of the differences that having a corporate client, as opposed to a human client, created in their obligations. They did not know that their roles as advisers generated different obligations from those generated by their roles as advocates. Finally, they were oblivious to the fact that the administrative process implies measures of candor different from those of the judicial process. The ultimate lesson of, National Student Marketing, then, is that ethical rules are not fungible. The lasting value of the case is that it may serve to help bring what lawyers consider extraordinary dilemmas within the realm of the manageable, msofar as the exercise of their discretion is concerned.

\section{CONCLUSION}

The law of legal ethics, by and large, is no better or worse than other bodies of law. The laws of contracts and torts have their deficiencies, too. One major difference is apparent here, however: the law of legal ethics is made by those whose conduct the rules are intended to guide. This may explam why the pace of change in the law of legal ethics has, until recent years, been glacial. One can surumse that it was the suddenness as much as the substance of the National Student Marketing case that caused so much furor.

The bar has survived the case so far, and it will contmue to do so. But National Student Marketing forecasts a change in the way in which lawyers must approach and deal with ethical problems in the future. The duty of loyalty to the client is no longer the sole criterion of ethical decisionmaking, and no longer is it possible, as has so often been true in the past, for lawyers to deal with ethical problems imtuitively. The standards of conduct for lawyers are fast becoming accepted as an integral part of the law im fact as well as im theory, and ethical problems are 
fast becoming subject to the same kind of analysis that lawyers have long applied to problems of their chents.

The aim of this Article has been to suggest some ideas that may aid the lawyer in analyzing ethical issues. In summary, the ideas are that rules of ethics are rules of law rather than rules of morahty; that the solution to ethical problems is not in the rights and duties of the lawyer, but in the rights and duties of the client; and, finally, that the factors relevant to the determination of those rights and duties are the nature of the client, the role of the lawyer, and the legal process involved.

These are simple, and on reflection obvious, ideas, but they are ideas that have been submerged under the notion of loyalty to the chent and lost in the undergrowth of ideas that surround the lawyer's role as advocate. Once expressed, these obvious ideas may lielp to provide the lawyer with a different and better perspective on his power and the consequences of its exercise. There is, however, a significant obstacle. People are convinced of nothing so much as they are convinced of their ability to determine right from wrong, lawyers not excepted. Confdence is a desirable quality, but such a universal conviction amounts to a human frailty of which lawyers should be especially conscious and careful, for obvious reasons. 